\title{
The Effect of Service Quality, Utilization of Information Technology, and Innovation on Marketing Performance of Savings and Loan Cooperative Putra Mandiri Surabaya
}

\author{
Vincent Audi Santoso, Sengguruh Nilowardono \\ Narotama University Surabaya \\ v_audi@yahoo.com
}

\begin{abstract}
This study aims to analyze the effect of service quality, utilization of information technology, and innovation on the marketing performance of Putra Mandiri Surabaya Savings and Loan Cooperatives partially and simultaneously. In this study the authors used accidental sampling techniques, where anyone who accidentally met with the researcher could be used as a sample. In this study, the number of samples the authors took as many as 130 people including members and prospective members of the cooperative. Data collection techniques used are using questionnaires and interviews. In calculating scoring, researchers used a Likert scale. The data analysis method used is multiple linear regression analysis. The results of this study indicate that the variables of Service Quality, Use of Information Technology, and Innovation have a significant effect on Cooperative Marketing Performance partially. Service Quality Variables, Information Technology Utilization, and Innovation have a significant effect on Cooperative Marketing Performance simultaneously.
\end{abstract}

Keywords: Service Quality, Use of Information Technology, Innovation, Improving Marketing Performance, Marketing Performance.

\section{INTRODUCTION}

The number of cooperatives in 2016 has increased dramatically compared to the total number of cooperatives in 2011. The growth of new cooperatives is as many as 18,574 spread throughout Indonesia. Related parties (KEMENKOP and UKM) in 2018 have created a database to find out how to design cooperatives going forward. From the results of the database compilation, data obtained from more than 200,000 cooperatives throughout Indonesia, around 80,000 were declared healthy cooperatives, 75,000 needed to be fostered and around 50,000 were dissolved because they were considered unhealthy. The amount is not a small amount and if it happens every year it is possible that in the next 10 or 15 years the cooperative will only have name and history.

The current condition of cooperatives in Indonesia can be said to be still stagnant and can even be said to be in decline. Need more attention so that cooperatives can experience development and not stagnate. Competitiveness and potential capabilities of cooperatives can be increased if cooperative business actors are able to provide optimal services to their members. In addition, the use of information technology will also play an important role in improving the performance of cooperatives. The main thing that should not be abandoned in the current era is the ability of the cooperative business sector to always innovate in the field of business, this is within the framework of always being able to meet the needs and desires of its members who are constantly changing. The things above are basically a very crucial factor and need to get attention in empowering cooperative sector businesses in the era of very competitive business competition today.

The Effect of Service Quality, Utilization of Information Technology, and Innovation on Marketing Performance of Savings and Loan Cooperative Putra Mandiri Surabaya 
The cooperative business empowerment sector aims to make the cooperative business sector empowered independently and economically in carrying out its business activities. If cooperatives can be economically independent, their performance will be very good.

Besides that, the quality of services, the use of information technology and innovation in business activities today is absolute and can be used as a competitive advantage for companies compared to other companies competing in the market. Based on the phenomenon.

business above, the writer then interested in lifting the business phenomenon into a topic of research on cooperative business empowerment sector with the title "the influence of service quality, information technology and innovation on the marketing performance of the cooperative business sector".

\section{LITERATURE REVIEW}

\subsection{Theoretical framework}

\section{1) Service Quality}

As we have seen, the better the quality of service provided, the greater satisfaction will be given to customers. In this case we can conclude that in general service has a meaning that is closely related to giving satisfaction to customers. Providing good service will make customers feel that their presence is being noticed by the service provider.

Service quality is an important factor that must be considered by every culinary businessman, in addition to the quality of the quality of food sold the quality of service also needs to be considered in order to get customer trust and become a driving factor in purchasing decisions.

According to Tjiptono (2014: 182) explained that service quality has five main dimensions, namely:

1. Reliability (reliability) is the ability to carry out appropriate services appropriately.

2. Responsiveness is the desire to help consumers and provide fast and valuable services.

3. Empathy (empathy) is a sense of caring and maintaining on each customer.

4. Assurance (certainty) is the knowledge and friendliness of employees and the ability to give the impression of being trustworthy and full of confidence.

5. Tangible is the appearance of physical facilities, equipment, personnel, and communication equipment.

\section{2) Information Technology}

One measure of the success of implementation in the utilization of information technology in the field of marketing can be seen at the level of achievement expected from users of information technology. System users reflect the acceptance of technology by their users (Venkatesh, 1999 in Shih, 2004: 7). The Technology Acceptance Model (TAM) has become the basis for past research in information systems relating to information technology behavior, intentions and users (adam et al, 1992: Dacis et al, 1989, Defend an Straub, 1997: Ambako-Gyampah and Salam, 2004 in Shih, 2004: 7)

Technology Acceptance Model (TAM) was developed by Davis (1989) by relying on Theory of Reasoned Action (TRA). TAM focuses on attitudes towards users of information technology, where users develop it based on perceptions of benefits and ease of use of information technology. The goal of TAM is to provide an explanation of the determinants of general computer acceptance. TAM is less common compared to TRA. TAM is designed only for the behavior of computer use, but because it combines various accumulated findings from research in several decades, the TAM is appropriate as modeling computer acceptance.

The Effect of Service Quality, Utilization of Information Technology, and Innovation on Marketing Performance of Savings and Loan Cooperative Putra Mandiri Surabaya 


\section{3) Innovation}

According to Everett M. Rogers, innovation is an idea, idea, motorcycle taxi, and practice that is based and accepted as a new thing by a person or a certain group to be applied or adopted.

According to Buchari Alma (2010: 10), the process of innovation is a personal factor that drives innovation itself, namely: the desire to achieve, the nature of curiosity, the desire to bear risk, educational factors and experience factors. While environmental factors encourage innovation is the existence of opportunities, experience and creativity. No doubt experience is a valuable teacher that triggers business pioneering, especially supported by opportunities and creativity.

Whereas according to Eddy Soeryanto Soegoto (2009: 8) the innovation process is the ability to add use value / benefits to a product and maintain product quality by paying attention to "market oriented" or what is being sold in the market.

Furman, 2002 (in Owano et. Al., 2014) states that service innovation focuses on making changes to the service process, this activity is carried out to attract more attention from consumers. In contrast to the Finnish technology and innovation agency, 2006 (in Dhewanto et al., 2013) which provides the notion that service innovation is a new concept or significant service improvement that is applied into business practices, for example new channels for customer interaction, distribution systems or technological concepts.

From the above understanding it can be concluded that service innovation is a renewal activity carried out by the company to improve services and produce new services.

\section{4) Marketing Performance}

Marketing performance is a measure of achievement obtained from the process of overall marketing activities of an organization. Lambin (in Ferdinan, 2000) places this measure of performance in the marketing system model into sales and profit output: Company sales, industry sales and market share, model cost prifit. Heneman (1997) measured performance with seven dimensions, namely: Total sales, total store, new store size, average store size, pre-tax profit growth rate, market share, expense sales gorwth ratio. namely:

While Ferdinand (2000) states that good marketing performance is stated in three main values,

(1) Sales

(2) Sales growth

(3) Customer growth

The three main values above boil down to company profits. The sales value shows how many rupiahs or units of product are sold, while sales growth shows how much sales of the same product increase compared to a certain time unit. Customer growth shows how much the contribution of products handled by customers in similar products compared to competitors.

Good marketing performance shows a high level of sales, an increase in the number of sales both in the product unit and in monetary units. Improved marketing performance is also characterized by good sales growth from year to year and higher growth than similar competitors and has broad customers compared to previous years (Ferdinan, 2000).

\subsection{Research Concept Framework}

Based on the research title that the author wants to examine, namely the Influence of Service Quality, Information Technology Utilization, and Innovation on Increasing the Performance of Putra Mandiri Surabaya Cooperative and the above descriptions, the conceptual framework of this research can be described as follows:

The Effect of Service Quality, Utilization of Information Technology, and Innovation on Marketing Performance of Savings and Loan Cooperative Putra Mandiri Surabaya 


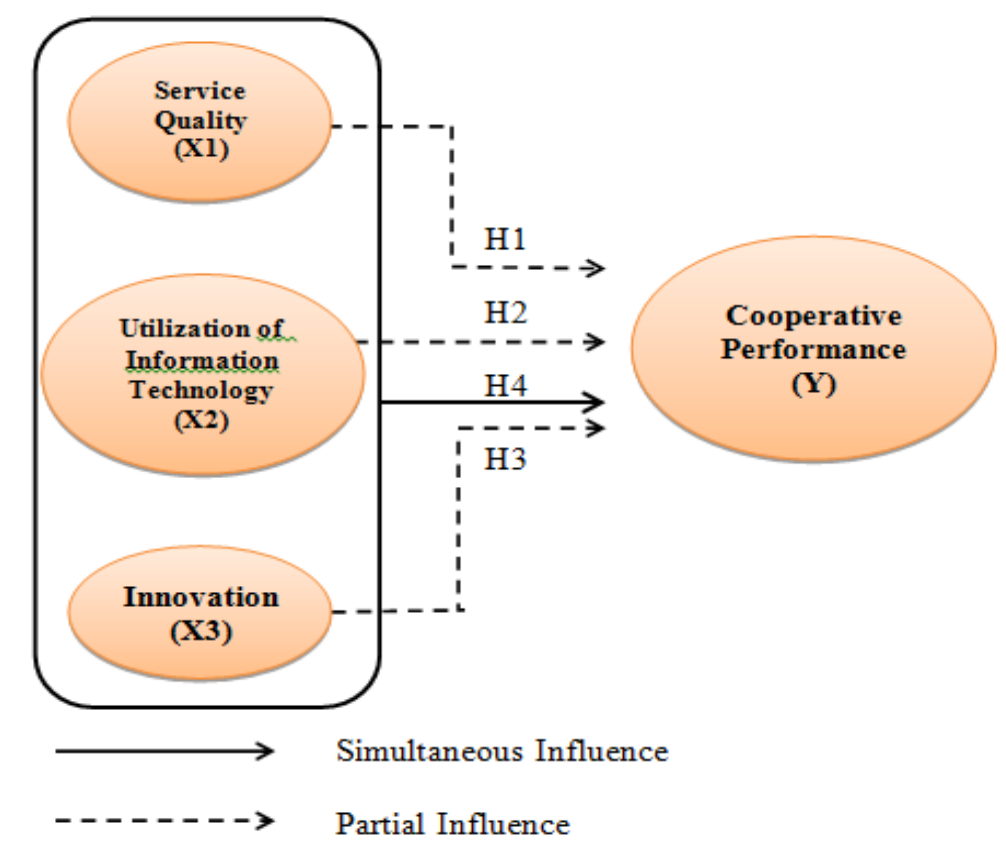

Source: Researcher (2018)

Figure 1. Research Concept Framework

\section{RESEARCH METHOD}

This research will be conducted with a survey method for members and prospective members of Putra Mandiri Savings and Loan Cooperative using a descriptive approach.

In this study the authors used accidental sampling techniques, where anyone who accidentally met with the researcher could be used as a sample. In the study the number of samples taken was 130 people who were members and prospective members of Putra Mandiri Surabaya Savings and Loan Cooperative. Thus the authors randomly choose each subject to get the chance to be selected as a sample.

The data source used is primary data. While the data collection techniques used are using questionnaires and interviews. Data processing techniques in this study consisted of quantitative and how to discuss it using the SPSS for Windows 18.0 program.

In this study, the author uses a Likert scale. Likert scale is used to measure attitudes, opinions, influences and perceptions of a person or group of people about social phenomena (Sugiyono: 2015). Likert scale is an interval scale so it can be analyzed using a parametric analysis tool such as regression analysis (Suliyanto: 2011). According to Ghozali (2010) also the Likert scale can be considered an interval.

The variables used in this study consist of independent variables (independent variables) and dependent variables (dependent variables). The independent variable (independent variable) in this research is Service Quality (X1), Utilization of Information Technology (X2), and Innovation (X3). Whereas the dependent variable (dependent variable) is Marketing Performance (Y).

\section{RESEARCH RESULTS AND DISCUSSION}

Putra Mandiri Surabaya Savings and Loan Cooperative is one of the cooperatives engaged in a savings and loan business that was established in Surabaya in 2016, based on the establishment deed No. P2T / 12 / 09.01 / 01 / IX / 2013, before Notary Victor Sidharta, S.H. .

The Effect of Service Quality, Utilization of Information Technology, and Innovation on Marketing Performance of Savings and Loan Cooperative Putra Mandiri Surabaya 
The work area of the Mandiri Surabaya Savings and Loan Cooperative at the beginning of its establishment only covered the Surabaya area, but over time the Putra Mandiri Surabaya Savings and Loan Cooperative has opened branches in the Surabaya city and its surrounding areas.

\subsection{Analysis of Test Validity and Reliability}

Test the validity and reliability of the questionnaire based on the results of the test by calculating the Pearson Product Moment correlation coefficient.

\section{1) Test Validity}

The results of testing the indicator validity of all the independent variables and the dependent variable are valid, because the value of the corrected item-total correlation (critical) is greater than the rtabel so it is stated that all research variables are valid.

\section{2) Reliability Test}

Reliability test is used to determine the reliability or consistency of the instrument (questionnaire) used. From the results of the reliability test, it can be seen that these variables are reliable, because all alpha values (rhit) are greater than 0.6 . Then all research variables are declared reliable.

\subsection{Result of Multiple Linear Regression Analysis}

Based on the results of the calculation of data processing with the help of the SPSS 18.00 for windows program, the following multiple linear regression equations are obtained in table 1:

Table 1 Results of Multiple Linear Regression Analysis

Coefficients $^{\mathrm{a}}$

\begin{tabular}{|c|c|c|c|c|c|c|c|c|c|c|}
\hline \multirow{2}{*}{ Model } & \multicolumn{2}{|c|}{$\begin{array}{c}\text { Unstandardized } \\
\text { Coefficients }\end{array}$} & \multirow{2}{*}{$\begin{array}{c}\text { Standardized } \\
\text { Coefficients }\end{array}$} & \multirow{2}{*}{$\mathrm{t}$} & \multirow{2}{*}{ Sig. } & \multicolumn{3}{|c|}{ Correlations } & \multicolumn{2}{|c|}{$\begin{array}{c}\text { Collinearity } \\
\text { Statistics }\end{array}$} \\
\hline & B & $\begin{array}{c}\text { Std. } \\
\text { Error }\end{array}$ & & & & $\begin{array}{l}\begin{array}{l}\text { Zero- } \\
\text { order }\end{array} \\
\end{array}$ & Partial & Part & Tolerance & VIF \\
\hline (Constant) & .02 & .329 & & .063 & .950 & & & & & \\
\hline Servic & .55 & 079 & .417 & 7.097 & .000 & 693 & .534 & 391 & 69 & 1.449 \\
\hline IT Utilization & .28 & .062 & .323 & 4.552 & .000 & 661 & .376 & .251 & .603 & 1.659 \\
\hline Innovation & .217 & .073 & .180 & 2.965 & .004 & .426 & .255 & 163 & .825 & 1.212 \\
\hline
\end{tabular}

a. Dependent Variable: Marketing Performance

Source: Appendix of SPSS Processing Results, Processed Data (Author, 2018)

Based on the results of the above calculations, obtained a multiple linear regression equation as following:

$$
\mathbf{Y}=0.021+0.559 \mathbf{X}_{1}+0.284 \mathbf{X}_{2}+0.217 \mathbf{X}_{3}+\mathbf{e}_{\mathbf{i}}
$$

The interpretation of the regression model above is as follows:

1. Constants $(\beta 0)=0.021$ indicate the magnitude of the Marketing Performance variable that is not influenced by the variable Service Quality (X1), Utilization of IT (X2), and Innovation (X3) or independent variable $=0$, the value of Marketing Performance is 0.021 .

2. The coefficient of Service Quality ( $\beta 1)$ is 0.559 indicating that if the Service Quality variable (X1) is increased, it will result in an increase in Marketing Performance of 0.559 assuming other variables are constant.

3. The IT Utilization coefficient ( $\beta 2)$ of 0.284 indicates that if the IT Utilization variable (X2) is increased, it will result in an increase in Marketing Performance of 0.284, assuming other variables are constant.

4. The value of the Innovation coefficient ( $\beta 3)$ is 0.217 indicating that if the Innovation variable (X3) is increased, it will result in an increase in Marketing Performance of 0.217, assuming other variables are constant.

5. $\quad e i$ shows the disturbing factors outside the model studied.

The Effect of Service Quality, Utilization of Information Technology, and Innovation on Marketing Performance of Savings and Loan Cooperative Putra Mandiri Surabaya 


\subsection{Analysis of the Correlation Coefficient and Determination Coefficient}

Table 2. Correlation Coefficient and Determination Coefficient

\begin{tabular}{|c|c|c|c|c|c|c|c|c|c|c|}
\hline \multicolumn{11}{|c|}{ Model Summary } \\
\hline \multirow[b]{2}{*}{ Model } & \multirow[b]{2}{*}{$\mathrm{R}$} & \multirow[b]{2}{*}{$\begin{array}{c}\mathrm{R} \\
\text { Square }\end{array}$} & \multirow{2}{*}{$\begin{array}{l}\text { Adjusted } \\
\text { R Square }\end{array}$} & \multirow{2}{*}{$\begin{array}{l}\text { Std. Error } \\
\text { of the } \\
\text { Estimate }\end{array}$} & \multicolumn{5}{|c|}{ Change Statistics } & \multirow{2}{*}{$\begin{array}{l}\text { Durbin- } \\
\text { Watson }\end{array}$} \\
\hline & & & & & $\begin{array}{c}\text { R Square } \\
\text { Change }\end{array}$ & F Change & df1 & $\mathrm{df} 2$ & $\begin{array}{c}\text { Sig. F } \\
\text { Change }\end{array}$ & \\
\hline dimension0 1 & $.785^{a}$ & .617 & .608 & .32899 & .617 & 67.653 & 3 & 126 & .000 & 1.927 \\
\hline
\end{tabular}

Correlation coefficient $(\mathrm{R})$ shows how closely the influence between the independent variables of Service Quality (X1), Utilization of IT (X2), Innovation (X3) with non-independent variables Y (Marketing Performance), the value of the correlation coefficient is 0.785 . This value indicates that the effect of Service Quality variable (X1), IT Utilization (X2), Innovation (X3), with Marketing Performance variables is to have a strong or strong influence.

The coefficient of determination or R2 is used to measure how far the ability of the model in explaining the variation of non-free variable (Y) is the variable of Labor Productivity. The results of the SPSS calculation obtained the value of $\mathrm{R} 2=0.608$ which means that $60.8 \%$ of Marketing Performance (Y) can be explained by the variables of Service Quality (X1), Utilization of IT (X2), Innovation (X3). While the remaining $39.2 \%$ is influenced by other variables outside the model studied.

\subsection{Hypothesos Testing}

Regarding the formulation of the problem and the research hypothesis proposed as described in the previous section, it can be explained that the variables that affect Marketing Performance are Service Quality (X1), IT Utilization (X2), Innovation (X3). And in this study the dependent variable is Marketing Performance which is variable $\mathrm{Y}$.

\section{1) Partial Testing of Hypotheses (T Test)}

To test the hypothesis used the $t$ test which shows the effect partially of each independent variable on the dependent variable (not free). At this stage, the effect of the independent variables contained in the model is formed to determine whether the independent variable $(\mathrm{X})$ in the model partially has a significant effect on the dependent variable (Y).

The Effect of Service Quality, Utilization of Information Technology, and Innovation on Marketing Performance of Savings and Loan Cooperative Putra Mandiri Surabaya 
Table 3. Results of Calculation of $T$ Test

Coefficients $^{\mathrm{a}}$

\begin{tabular}{|c|c|c|c|c|c|c|c|c|c|c|}
\hline \multirow{2}{*}{ Model } & \multicolumn{2}{|c|}{$\begin{array}{c}\text { Unstandardized } \\
\text { Coefficients }\end{array}$} & \multirow{2}{*}{$\begin{array}{c}\begin{array}{c}\text { Standardized } \\
\text { Coefficients }\end{array} \\
\text { Beta }\end{array}$} & \multirow{2}{*}{$\mathrm{t}$} & \multirow{2}{*}{ Sig. } & \multicolumn{3}{|c|}{ Correlations } & \multicolumn{2}{|c|}{$\begin{array}{c}\text { Collinearity } \\
\text { Statistics }\end{array}$} \\
\hline & B & $\begin{array}{l}\text { Std. } \\
\text { Error }\end{array}$ & & & & $\begin{array}{l}\text { Zero- } \\
\text { order }\end{array}$ & Partial & Part & Tolerance & VIF \\
\hline $1 \quad$ (Constant) & .021 & .329 & & .063 & .950 & & & & & \\
\hline Service Quality & .559 & .079 & .417 & 7.097 & .000 & .693 & .534 & .391 & .690 & 1.449 \\
\hline IT Utilization & .284 & .062 & .323 & 4.552 & .000 & .661 & .376 & .251 & .603 & 1.659 \\
\hline Innovation & .217 & .073 & .180 & 2.965 & .004 & .426 & .255 & .163 & .825 & 1.212 \\
\hline
\end{tabular}

a. Dependent Variable: Marketing Performance

Source: Appendix of SPSS Processing Results, Processed Data(Author, 2018)

Partial Test Between Service Quality Variables (X1) Against Variable Marketing Performance (Y)

To test the hypothesis used the $t$ test which shows the partial effect of the Service Quality variable (X1) on the Marketing Performance variable (Y).

Hypothesis:

a) $\mathrm{H}_{0}: \beta 1=0$ (That is, the Service Quality variable (X1) does not have a significant effect on the variable Marketing Performance)

b) $\mathrm{H}_{1}: \beta 1 \neq 0$ (That is, the Service Quality variable (X1) has a significant influence on the Marketing Performance variable)

c) $\alpha=0.05$ with df $(\mathrm{n}-\mathrm{k}-1)=126$ where $\mathrm{t}_{\text {table }}=1,657$

d) $t_{\text {count }}=7,097$ with a significance level of 0,000

e) Conclusion:

Based on SPSS version 18.00 output obtained tcount of 7,097 greater than ttable of 1,657 or significant level $(0,000<0.05)$ then $\mathrm{H}_{0}$ is rejected at $5 \%$ significance level so that the conclusions partially Service Quality variable (X1) has a significant influence on Marketing Performance (Y).

Partial Test Between Variables of IT Utilization (X2) Against Variable Marketing Performance (Y)

To test the hypothesis used the t test which shows the partial effect of the IT Utilization variable

(X2) on the Marketing Performance variable (Y).

Hypothesis :

a) $\mathrm{H}_{0}: \beta_{2}=0$ (That is, the variable IT Utilization (X2) does not have a significant effect on the variable Marketing Performance)

b) $\mathrm{H}_{1}: \beta_{2} \neq 0$ (That is, the variable IT Utilization (X2) has a significant effect on the variable Marketing Performance)

c) $\alpha=0,05$ with $\mathrm{df}(\mathrm{n}-\mathrm{k}-1)=126$ where $\mathrm{t}_{\text {table }}=1.657$

d) $\mathrm{t}_{\text {count }}=4.552$ with a significance level of 0.000

e) Conclusion: :

Based on SPSS version 18.00 output obtained $t_{\text {count }}$ of 4.552 greater than $t_{\text {table }}$ of 1.657 or significant level $(0.000<0.05)$ then $\mathrm{H}_{0}$ is rejected at $5 \%$ significance level so that the conclusion is partially IT Utilization variable (X2) has a significant influence on Marketing Performance (Y).

Partial Test Between Innovation Variables (X3) Against Variable Marketing Performance (Y)

To test the hypothesis, the $\mathrm{t}$ test is used which shows the partial effect of the Innovation variable (X3) on the Marketing Performance variable (Y).

Hypothesis:

a) $\mathrm{H}_{0}: \beta_{3}=0$ (That is, the Innovation variable (X3) does not have a significant effect on the variable Marketing Performance)

b) $\mathrm{H}_{1}: \beta_{3} \neq 0$ (That is, the Innovation variable (X3) has a significant effect on the variable Marketing Performance)

The Effect of Service Quality, Utilization of Information Technology, and Innovation on Marketing Performance of Savings and Loan Cooperative Putra Mandiri Surabaya 
c) $\alpha=0$, with df $(\mathrm{n}-\mathrm{k}-1)=126$ where is $\mathrm{t}_{\text {table }}=1.657$

d) $t_{\text {count }}=2.965$ with a significance level of 0.004

e) Conclusion :

Based on SPSS version 18.00 output obtained $t_{\text {count }}$ of 2.965 greater than $t_{\text {table }}$ of 1,657 or significant level $(0.004<0.05)$ then $\mathrm{H}_{0}$ is rejected at $5 \%$ significance level so that the conclusion of the Innovation variable partially (X3) has a significant influence on Marketing Performance (Y).

Thus the authors conclude that the second hypothesis which states "That Service Quality, Utilization of Information Technology, and Innovation partially influences Marketing Performance" is proven empirically.

\section{2) Simultaneous Testing of Hypotheses (F Test)}

Simultaneous test (F test) shows that all independent variables consisting of Service Quality (X1), Utilization of IT (X2), Innovation (X3), have a significant (significant) effect on the dependent variable of Marketing Performance (Y).

Table 4. Results of Calculation of $F$ Test

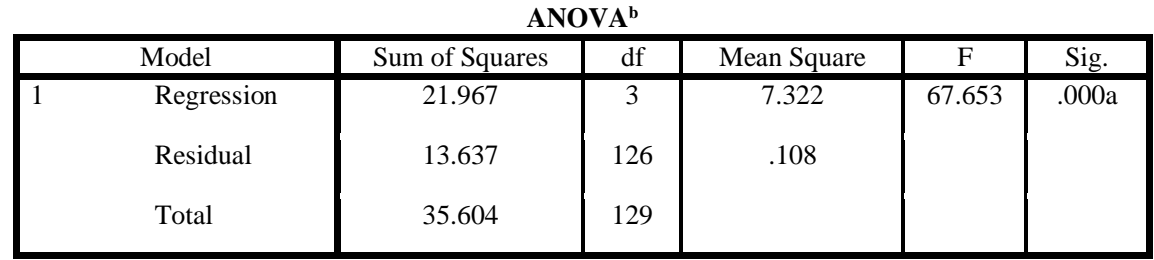

a. Predictors: (Constant), Service Quality, IT Utilization, Innovation

b. Dependent Variable: Marketing Performance

Source: Appendix of SPSS Processing Results, Processed Data (Author, 2018)

Steps:

(1) Hypothesis:

$H_{0}: b_{1}=b_{2}=b_{3}=0$ means that the variables $\mathrm{X} 1, \mathrm{X} 2, \mathrm{X} 3$ do not affect the dependent variable $(\mathrm{Y})$.

$H_{1}: b_{1} \neq b_{2} \neq b_{3} \neq 0$ means that variables $\mathrm{X}_{1}, \mathrm{X}_{2}, \mathrm{X}_{3}$ have an influence on the dependent variable (Y).

(2) Amount of value:

$F_{\text {table }}=F \alpha(d f$ regression, residual $d f)=\mathrm{F} \alpha(\mathrm{k}, \mathrm{n}-\mathrm{k}-1)$

$F_{\text {table }}=F 0.05(3,126)=2.68$

(3) Critical areas or areas of rejection

If $F_{\text {count }} \geq F_{\text {tabel }}$ then $H_{0}$ is rejected

If $F_{\text {count }}<F_{\text {tabel }}$ then $H_{0}$ is accepted

(4) $\quad F_{\text {count }}=15.166$

(5) Kesimpulan:

Because of $F_{\text {count }}>F_{\text {table }}$ yaitu $67.653>2.68$ or a significance value of $0.000<0.05$, then $H_{0}$ is rejected at a 5\% significance level so that it can be concluded that all independent variables are Service Quality (X1), IT Utilization (X2), Innovation (X3), influences simultaneously on the dependent variable of Marketing Performance (Y). Thus the first hypothesis which states "That the quality of services, the use of information technology, and innovation have a simultaneous effect on Cooperative Performance" is empirically proven to be true.

Thus the second hypothesis which states that "Service Quality, Utilization of Information Technology, and Innovation simultaneously affect Marketing Performance" empirically proved the truth.

\section{3) Dominant Variables}

The Effect of Service Quality, Utilization of Information Technology, and Innovation on Marketing Performance of Savings and Loan Cooperative Putra Mandiri Surabaya 
Partial $t_{\text {count }}$ shows how closely the relationship between the independent variables including service quality (X1), Information Technology Utilization (X2), Innovation (X3), partially has a significant effect on the dependent variable Marketing Performance (Y).

Table 5. $t_{\text {count }}$ The Independent Variable

\begin{tabular}{|l|c|c|}
\hline \multicolumn{1}{|c|}{ Variable } & $\boldsymbol{t}_{\text {count }}$ & sig \\
\hline Service Quality (X1) & 7.097 & .000 \\
\hline IT Utilization (X2) & 4.552 & .000 \\
\hline Innovation (X3) & 2.965 & .004 \\
\hline
\end{tabular}

Based on the data obtained in Table 420 above, it can be seen that the largest $\mathrm{t}$ value is for Service Quality (X1) variable of 7,097, meaning that the Service Quality variable (X1) partially has the most dominant influence on the Surabaya Independent Savings and Loan Cooperative Marketing Performance.

\subsection{Discussion}

Based on the results of calculations with multiple linear regression analysis the model regression equation below is obtained:

$$
\mathbf{Y}=0.021+0.559 \mathbf{X}_{1}+0.284 \mathbf{X}_{\mathbf{2}}+0,217 \mathbf{X}_{\mathbf{3}}+\mathbf{e}_{\mathbf{i}}
$$

From the acquisition value of the model regression equation, it is known that service quality variables (X1), utilization of information technology (X2), innovation (X3) show positive regression coefficient values, this indicates a positive direction or directional effect of service quality variables. (X1), utilization of information technology (IT) (X2), innovation (X3) on Cooperative Marketing Performance. This can be interpreted that if service quality increases (X1), utilization of information technology (IT) (X2), innovation (X3), Cooperative Marketing Performance will increase, and vice versa if service quality decreases (X1), technology utilization information (IT) (X2), innovation (X3) then the Cooperative Marketing Performance will decrease. To estimate the value of e, it can be searched with the following formulations:

$$
\begin{array}{ll}
e & =\operatorname{SEE} \times t_{\text {tabel }} \\
e & =0.32899 \times 0.1657 \\
e & =0.0545
\end{array}
$$

Thus the formulation of the regression becomes as follows :

$\mathbf{Y}=0.021+0.559 \mathbf{X}_{\mathbf{1}}+0.284 \mathbf{X}_{\mathbf{2}}+0,217 \mathbf{X}_{\mathbf{3}}+0.0545$

The results of the analysis show variable service quality (X1), utilization of information technology (IT) (X2), innovation (X3) simultaneously (together) significantly influence Marketing Performance (Y). This is known from the results of the $F$ test which shows that the value of $F$ count> $F$ table is $67,653>15.166$ and with the probability of error the model being tested is 0,000 which means the probability is smaller than the significance level of 0.05 , so the effect of all independent variables (X1), the use of information technology (IT) (X2), innovation (X3) on the dependent variable (Cooperative Marketing Performance) is meaningful. Thus the first hypothesis of the study reads "service quality variable (X1), information technology utilization (X2), innovation (X3) has a simultaneous effect on Cooperative Marketing Performance "empirically proven true..

All independent variables or independent variables have an effect or can explain the variation of the dependent variable by $60.8 \%$. This is evidenced by seeing the value of the coefficient of determination (Adjusted R Square) of 0.608 from the results of multiple linear regression analysis using the SPSS statistical program as in Appendix 3, while the remaining 39.2\% is influenced by other factors

The Effect of Service Quality, Utilization of Information Technology, and Innovation on Marketing Performance of Savings and Loan Cooperative Putra Mandiri Surabaya 
outside the model. Correlation coefficient (R) indicates the relationship or influence of attachment between the independent variables of service quality variable (X1), utilization of information technology (IT) (X2), innovation (X3) together with Cooperative Marketing Performance (Y) that is strong or tight, because it shows a number of 0.785

The results also show that service quality variables (X1), utilization of information technology (IT) (X2), innovation (X3) partially have a significant effect on Marketing Performance. This can be seen from the magnitude of the tcount $>\mathrm{t}$ table at each independent variable. This is in line with Lien's opinion, 2012 (in Delafrooz et. Al., 2013), which states that new activities in the service business are considered as new services or service innovations. This activity can be seen from the technology used, interaction with customers, development of new services. The renewal of the technology by the company will accelerate the services provided to consumers, as well as the development of services that the company will make a variety of services to consumers so that the perceived service will be different from the services provided by the previous company so that consumers are satisfied with the service provided services on other occasions. The service innovation process carried out by the company will make the company more focused and efficient in its operational structure. This requires a change in the internal structure so that it will make production increase and the customer service process will be carried out quickly in Riepula, 2009 (in Owano, 2014).

Seeing this condition, means Putra Mandiri Surabaya Savings and Loan Cooperative has implemented the principles of Cooperative empowerment launched by the government through the Cooperative Ministry program, so that the number of cooperatives is expected to grow and become more healthy, and in turn this will be able to reducing the number of inactive cooperatives, especially those in Surabaya and East Java in general.

\section{CONCLUSIONS AND SUGGESTIONS}

\subsection{Conclusion}

Berdasarkan uraian dan pembahasan diatas dapat ditarik kesimpulan sebagai berikut:

a) Variabel kualitas layanan (X1), pemanfaatan teknologi informasi (IT) (X2), inovasi (X3) secara simultan (bersama-sama) berpengaruh secara signifikan terhadap Kinerja Pemasaran (Y). Hal tersebut menunjukkan bahwa hipotesis pertama yang berbunyi "variabel kualitas layanan (X1), pemanfaatan teknologi informasi (X2), inovasi (X3) berpengaruh secara simultan terhadap Kinerja Pemasaran Koperasi ” secara empiris terbukti kebenarannya.

b) Variabel kualitas layanan (X1), pemanfaatan teknologi informasi (IT) (X2), inovasi (X3) secara parsial berpengaruh signifikan terhadap Kinerja Pemasaran. Hal tersebut menunjukkan bahwa hipotesis kedua yang berbunyi "variabel kualitas layanan (X1), pemanfaatan teknologi informasi (X2), inovasi (X3) berpengaruh secara parsial terhadap Kinerja Pemasaran Koperasi ” secara empiris terbukti kebenarannya.

c) Hasil penelitian juga menunjukkan bahwa variabel kualitas layanan merupakan variabel dominan yang mempengaruhi kinerja pemasaran Koperasi Simpan Pinjam Mandiri.

\subsection{Suggestion}

Based on the results of the research as a whole and the conclusions obtained, several suggestions can be developed for interested parties in this study. The suggestions put forward are as follows:

a) Putra Mandiri Surabaya Savings and Loans Cooperative should further improve or maintain the quality of its services to all members / customers in conducting any transaction activities so that this is expected to increase trust and pride for members / customers to become members / customers of Cooperative Save Borrow Putra Mandiri Surabaya.

b) Putra Mandiri Surabaya Savings and Loans Cooperative should always develop new innovations in the field of service and cooperative products offered to its members / customers, so that in the future members / customers of the Mandiri Surabaya Savings and Loan Cooperative will have a wide choice of products and services can be used by every member / customer.

The Effect of Service Quality, Utilization of Information Technology, and Innovation on Marketing Performance of Savings and Loan Cooperative Putra Mandiri Surabaya 
c) The next researcher is expected to be able to enter and add other variables as independent variables, so that further research will be made known later other variables that greatly affect the marketing performance of cooperatives. This is important because from the results of the research that the author did, it turns out that the independent variable studied consisting of service quality (X1), IT utilization (X2), and innovation (X3) is only able to predict marketing performance of $60.8 \%$.

\section{REFERENCES}

Davis, F. D. (1985). A technology acceptance model for empirically testing new end-user information systems: Theory and results. Management. https://doi.org/oclc/56932490

Davis, F. D. (1989). Perceived usefulness, perceived ease of use, and user acceptance of information technology. MIS Quarterly: Management Information Systems, 13(3), 319-339. https://doi.org/10.2307/249008

Everett M Rogers (1983). Diffusi of Innovations, third edition. New York: The Free Press.

Ferdinand, Augusty. 2011. Metode penelitian manajemen.Semarang:Undip.

Sugiyono. (2009). Metode Penelitian Bisnis (Pendekatan Kuantitatif, Kualitatif, dan R\&D). Bandung: Alfabeta.

Ghozali,Imam.2011. Aplikasi Analisis Multivariate Dengan Program Ibm Spss 19.Semarang:Undip

The Effect of Service Quality, Utilization of Information Technology, and Innovation on Marketing Performance of Savings and Loan Cooperative Putra Mandiri Surabaya 